\title{
The Effect of Self-Efficacy on Entrepreneurial Intention with the Mediation Variables of Attitude Towards Behavior, Perceived Behavioral Control and Subjective Norm (a Study on the Master's of Management Students at Universitas Ciputra Surabaya)
}

\section{Briandy Putra ${ }^{1}$ and Tony Antonio ${ }^{2}$}

${ }^{1}$ Magister Management Program, Universitas Ciputra, Surabaya, Indonesia

${ }^{2}$ Faculty of Management and Business, Magister Management Program, Universitas Ciputra, Surabaya, Indonesia

ORCID:

Tony Antonio: $h$ ttp://orcid.org/0000-0003-1157-9081

Corresponding Author:

Tony Antonio

tonyantonio@ciputra.ac.id

Published: 22 March 2021

Publishing services provided by Knowledge E

(c) Briandy Putra and Tony Antonio. This article is distributed under the terms of the Commons Attribution License, which permits unrestricted use and redistribution provided that the original author and source are credited.

Selection and Peer-review under the responsibility of the ICOEN Conference Committee.

\section{Abstract}

Entrepreneurship education is one of the national programs to boost the number of entrepreneurs in the country. The success of creating educated entrepreneurs depends on several factors such as the curriculum, mentors, the method and the readiness of the participant. The intention to become an entrepreneur cannot be separated from the individual's self-efficacy. This research examined the effect of master's students' self-efficacy on their entrepreneurial intention, with the mediation of the Planned Behavior Theory variables. The sample included 134 master's students out of the total of 203. All had been conducting business for at least six months and were recruited through purposive sampling. A 1-5 Likert scale questionnaire was given to the respondents in print and through Google Forms. Quantitative data analysis was done using smart-PLS version 3. Two of the three variables of the Planned Behavior Theory were significant as mediators of self-efficacy, namely attitude toward behavior and subjective norm. Perceived behavioral control did not have an effect on self-efficacy and entrepreneurial intent through mediation.

Keywords: Self-efficacy, Theory of planned behavior, Attitude Toward Behavior, Perceived Behavioral Control, Subjective Norm, Entrepreneurial Intention

\section{Introduction}

The existence of entrepreneurs is needed to make Indonesia a developed country. Indonesia still must create many entrepreneurs to become a developed country. Until 2019 , the number of entrepreneurs in Indonesia was still 3.1\% of the total population., 
said the Executive Director of the Indonesian Employers Association. To achieve the ideal number, Indonesia, arguably, is still missing because of the optimal number is $4 \%$,according to Hal Udisubakti, Dean of the ITS Faculty of Business and Technology Management [1].

To become an entrepreneur, an individual must have strong, confident behavior to become a successful entrepreneur. According to Astri \& Latifah (2017), there are three reasons why people are not interested in entrepreneurship, (1) the level of personal attributes/level of the person's own personality, (2) the level of facing difficulties It is not properly educated because it is used to an instantaneous society, or challenges due to pressure resistance. (3) Less optimal self-efficacy [2].

As a university that develops and is based on entrepreneurship, Ciputra University has created graduates who have the capacity and spirit of entrepreneurship as expected by the founder of the Ciputra group itself. Ciputra University Masters has integration lessons each semester and is divided into two main focuses, namely family business, and corporate entrepreneurship management.

\section{Methods}

\subsection{Research Type}

This study uses smart PLS quantitative research as the tool of research interpretation..

\subsection{Population and Sample}

The population of the study is 204 active master students in entrepreneurship management at Ciputra University. ased on calculations of the Slovin formula, The samples taken in this analysis contained 134 individuals. With the criteria of getting at least six months of business operation. The sampling method is purposive sampling

\subsection{Data Collection Method}

The data collection method used was a questionnaire. This measurement also used a Likert scale of 1- 5 . 


\subsection{Research Variables}

The research has three types of variables such as independent variable, dependent variable and mediating variable. The dependent variable is Entrepreneurial Intention $(Y)$ and Self-efficacy is the independent variable (X-1). There are three mediating variables; and marked as X-1, while entrepreneurial intention here is one independent variable Attitude Toward Behavior X-2, Perceived Behavioral Control X-3 and Subjective Norm $\mathrm{X}-4$.

\subsection{Validity and Reliability}

\subsubsection{Validity}

Testing is done to compare the results of the calculated $r$-value and $r$ table for the degree of freedom (df) $=n-2$, and $n$ is the number of samples and alpha $=0.05$. Ghozali (2011) in Saryanto (2017) stated that a questionnaire is valid or valid if the calculated $r$-value is bigger than the $r$ table value and is positive [3]. The validity of this analysis used the Pearson correlation, that is, by correlating the item scores with their overall scores. Significance research has been conducted using the parameters the $r$ table at a significance level of 0.05 . If the value is positive and $r$ count $\geq r$ table, then the item can be declared valid, and vice versa (Priyanto 2014) [4].

\subsubsection{Reliability}

The method used in this study to measure the range scale is Cronbach Alpha. According to Priyanto (2014) reliability $<0.6$ is not good, while 0.7 is acceptable and $>0.8$ is good [4].

\subsection{Data Analysis}

In this study, the data analysis method used is structural equation modeling (SEM). This study's path analysis is partial least square (PLS), using the SmartPLS 3.0 software.

\subsubsection{Designing a Structural Model (Inner Model)}

Assessing the model using the PLS can begin by looking at the R-square for each latent dependent variable. The interpretation will be the same as the interpretation in 
regression. PLS can also be evaluated by looking at the Q-square predictive relevance to see a constructive model. The $Q$-square value $>0$ indicates that the model has predictive relevance value, while the $\mathrm{Q}$-square value $<0$ indicates that the model lacks predictive relevance value Ghozali (2014).

\subsubsection{Designing the Measurement Model (Outer Model)}

1. Convergent Validity

In this evaluation, an individual item reliability check can be seen from the standardized loading factor. The standardized loading factor can describe the magnitude of the correlation between each indicator and its construct. Correlation can be valid if it has a value> 0.5 Ghozali (2014).

\section{Discriminant Validity}

This measurement model can be assessed based on the measurement of cross loading along with the construct. If the correlation between each indicator's constructs is more significant than the size of the other constructs, the latent construct can predict the indicators better than other constructs. The AVE criterion value must be $>0.5$ as a condition of the reliability of Sholihin (2013).

3. Composite Reliability

After testing the construct validity, a test is conducted for construct reliability, which can be measured by two criteria: composite reliability and Cronbach alpha. A good Cronbach alpha is a value that has more than 0.7 Sholihin (2013)

\subsubsection{Path Diagram Construction}

When the design and determination of the outer model and inner model to be tested have been carried out, then the outer and inner models are translated in the form of a path diagram.

\subsubsection{Estimation: Path Coefficient, Loading}

Parameter estimates obtained from PLS (Partial Least Square) can be categorized into thr ee:

1. Reflects the path estimate linking latent variables and between latent variables and their indicator blocks (loading). 
2. With regards to means and location parameters (regression constant values) for indicators and latent variables Ghozali (2014).

\subsubsection{Resampling Bootstrapping}

To see the important influence of looking at the coefficient on hypothesis tests using bootstrapping The value of the parameter and the t-statistic significance value. The $t$ value of $10 \%$ significance table $=1.65$. Therefore, the resulting statistical $t$ value must be bigger than 1.65 Ghozali (2014)

\subsubsection{SEM Analysis with Mediation Effects}

The mediation effect test was carried out by looking at the t-statistic value in the total effect. Abdillah in Jogiyanto (2015) stated that the mediation effect test can not only be done in testing with a direct relationship between the independent variable and the dependent variable. However, the relationship cannot be direct with the independent variable and the dependent variable because the results of the total effect are used to see the prediction's total effect.

\section{Results}

\subsection{Respondents Characteristics}

The research respondents were involved students of MIM at Ciputra University from batch $16,17,18,19,20$. The total of the active Ciputra University MIM student population is 203. Using the Slovin formula, 135 samples were taken with the minimum requirements of having had a company or operating a business for at least six months or longer.

\subsection{Descriptive Analysis of Research Variables}

\subsubsection{Descriptive analysis of self-efficacy}

From the research result, it can be known that the description of the respondents' answers to the self - efficacy variable has an average value of 4.091, which falls into the agreed category. The lowest standard deviation is owned by the X1.4 indicator, namely 
0.688, which means that the respondent's answer to this indicator is the most homogeneous compared to the respondent's answer to other indicators because students agree that they have strong confidence in starting a business.

\subsubsection{Descriptive analysis of attitude toward behavior}

The description of the respondent's answer to the attitude toward behavior variable has an average value of 4.202 , which falls into the agreed category. The lowest standard deviation is the $\mathrm{X} 2.8$ indicator, namely 0.374 , which means that the respondent's answer to this indicator is the most homogeneous compared to the respondent's answer to other indicators because students feel they can face challenges.

\subsubsection{Descriptive analysis of perceived behavior control}

The description of respondents' answers to the variable perceived behavior control has an average value of 4.234 , which falls into the agreed category. The lowest standard deviation is owned by the X3.1 indicator, namely 0.724 , which means that the respondent's answer to this indicator is the most homogeneous compared to the others because students agree with the belief that is a factor make the behavior do something.

\subsubsection{Descriptive analysis of subjective norms}

The descriptions of respondents' answers to the variable subjective norm have an average value of 4.413 , which falls into the agreed category. The lowest standard deviation is owned by the $X 4.3$ indicator, which is 0.581 , which means that the respondent's answer to this indicator is the most homogeneous compared to the respondent's answer to other indicators because students agree that lecturers are considered supportive of entrepreneurship.

\subsubsection{Descriptive analysis of Entrepreneurial Intention}

The description of respondents' answers to the Entrepreneurial Intention variable Has an average value of 4.459 , which falls into the agreed category. The lowest standard deviation is the $Y 1.3$ indicator, which is 0.593 , which means that the respondent's answer 
to this indicator is the most homogeneous compared to the respondent's answer to other indicators because students agree that they want to start a business.

\subsection{Evaluation of Outer Model Measurement}

Evaluation of the outer model fulfills two requirements, namely validity and reliability. Validity is seen through convergent validity and discriminant validity.

\subsection{Inner model evaluation}

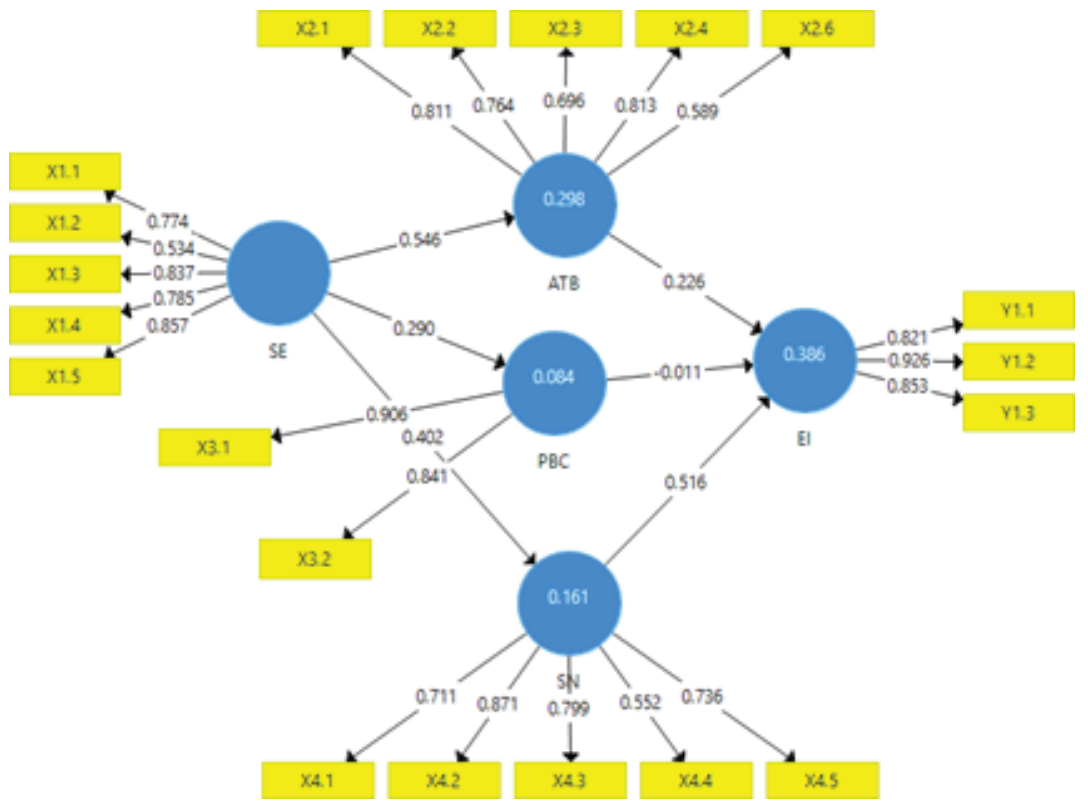

Figure 1: Path Diagram Source: Data processed through PLS, 2020

\subsubsection{R-square}

The r-square test results show that the variable self-efficacy affects attitude toward behavior by $29.8 \%$. Self-efficacy-efficacy affects entrepreneurial intention by $38.6 \%$, selfefficacy affects Perceived Behavioral Control by $8.4 \%$, self-efficacy affects subjective norm by $16.1 \%$.

\subsubsection{Q-square test}

Based on the Q-square results, it can be seen that this model has a good predictive relevant value because the q-square value is greater than 0 . It can also be concluded 
that this model has been well observed, and the mediation variable has a predictive value for entrepreneurial intention.

\subsubsection{F-Square Test}

There is one variable that has no relationship with the $F$ value of 0,000 in this study, namely Perceived Behavioral Control with Entrepreneurial Intention, while the highest value or the strongest relationship among self-efficacy variable is attitude toward behavior with value 0.424 , then the second is subjective norm with a value of 0.192 and the last is Perceived Behavioral Control at 0.092. For Entrepreneurial intention, the strongest relationship between these variables is the subjective norm with a value of 3.369 and then attitude toward behavior of 0.066 .

\subsubsection{T-test}

All hypotheses have a value of $\mathrm{T}>1.65$ except for the relationship between variables of Perceived Behavioral Control on entrepreneur intention with a t-statistic value of 0.134 , so it can be concluded that there is one hypothesis that is not accepted from all the hypotheses in this study.

\subsection{Estimation: Path Coefficient, Loading}

\subsubsection{Path coefficient}

Each variable has a positive addition when viewed from the original sample, except for the variable perceived behavior control towards entrepreneurial intention with a value of -0.011 , which means that if there is an added value to the perceived behavior control, it will reduce 0.011 units on Entrepreneurial Intention.

\subsubsection{Loading path}

From the research result, it can be known that all the indicators of this study get a valid correlation because all values of the loading factor are $>0.5$ 


\subsection{Mediating effect test}

The mediation effect of planned behavior theory does not affect the relationship between self-efficacy and entrepreneurial intention. It is proven that the t-statistic value of self-efficacy on Entrepreneurial intention through mediation perceived behavior control is smaller than 1.65, which becomes t statistic standard, Ghozali(2014). But the other two mediating variables have values above the standard of the t statistic, namely 3.126 for the attitude toward behavior mediation variable and 3.653 for the subjective norm variable.

\section{Discussion}

\subsection{Self-efficacy has a significant effect on attitude toward behav- ior}

Based on the results of statistical calculations carried out in this study, it can be concluded that $(\mathrm{H} 1)$ is accepted, and it is stated that there is a significant influence between self-efficacy on attitude toward behavior as proven with the analysis path value of 0.546 , and because the $t$ value $>1.65$ is 9.165 . So that it can be seen in this study that the self-efficacy of Ciputra University students has a significant and positive effect on attitude toward behavior.

\subsection{Self-efficacy significantly has a significant effect on Perceived Behavior Control}

Based on statistical calculations, this research can conclude that $(\mathrm{H} 2)$ is accepted and stated that a significant difference between self-efficacy to Perceived Behavioral Control is proven with the analysis path value of 0.290 . It is due to the $t$ value $>1.65$, namely 3.165. So it can be seen in this study that the self-efficacy of Ciputra University students has a significant and positive effect on Perceived Behavioral Control.

\subsection{Self-efficacy has a significant effect on subjective norm.}

Based on the results of statistical calculations, it can be concluded that $(\mathrm{H} 3)$ is accepted, and it is stated that there is a significant influence between self-efficacy on subjective norm, as evidenced by the path value of analysis of 0.402 . It is because of the value 
of $t$ count> 1.65 , which is 5.616 . So it can be seen in this study that the self-efficacy of Ciputra University students has a significant and positive effect on subjective norms.

\subsection{Attitude toward behavior has a significant effect on Entrepreneurial Intention}

Based on the results of statistical calculations carried out in this study, it can be concluded that $(\mathrm{H} 4)$ is accepted. It is stated that there is a significant influence between attitude toward behavior on Entrepreneurial intention, as evidenced by the path value of analysis of 0.229 and caused by the value of $t$ count $>1.65$, which is 3.362 . So it can be seen in this study that the attitude toward behavior of Ciputra University students has a significant and positive effect on entrepreneurial intention.

\subsection{Perceived Behavioral Control does not have a significant effect on Entrepreneurial Intention.}

Based on the results of statistical calculations carried out in this study, it can be concluded that $(\mathrm{H} 5)$ is rejected. It is stated that there is no influence between Perceived Behavioral Control on Entrepreneurial Intention because the value of the path of analysis shows a negative number, namely -0.011 and also because the value of $t$ count $<1.65$ is 0.134 . So it can be seen in this study that the Perceived Behavioral Control of Ciputra University students does not have a significant effect and shows a negative value on entrepreneurial intention. When viewed from the AVE value, it can be said that this variable is a good variable because it has a high enough AVE value, namely 0.753 . The outer loading value generated by this variable is also quite good with a high value in the indicator which talks about confidence, which can be a factor that makes it easy or difficult to do something is at a value of 0.950 , which is one of the indicators that have the highest value compared to the value of other indicators and also the second indicator, namely the perception of fighting power which is a factor that supports or even hinders behavior as an entrepreneur with an outer loading value of 0.841 and what researchers can interpret is that indicators of this variable are deemed insufficient to assess the level of influence of perceived behavior control on entrepreneurship. intention, many other indicators may be included in the depth of this research. 


\subsection{Subjective norms have a significant effect on Entrepreneurial Intention}

Based on the results of statistical calculations carried out in this study, it can be concluded that $(\mathrm{H} 6)$ is accepted, and it is stated that there is a significant influence between subjective norms on Entrepreneurial intention as evidenced by the path value of analysis of 0.516 and due to the $t$ value. count $>1.65$ which is 5,966 . So it can be seen in this study that the subjective norms owned by Ciputra University students have a significant and positive effect on entrepreneurial intention.

\subsection{Attitude toward behavior has a significant effect as a mediator of self-efficacy on Entrepreneurial Intention.}

Based on the results of statistical calculations carried out in this study, it can be concluded that $(\mathrm{H} 7)$ is accepted, and it is stated that there is a significant influence between the attitude toward behavior variable when mediating self-efficacy on Entrepreneurial intention is evidenced by the $t$ value $>1.65$, which is 3.126 . So it can be seen in this study that attitude toward behavior has a significant effect as a mediator of self-efficacy on Entrepreneurial Intention. Perceived Behavioral Control has no significant effect as a mediator of self-efficacy on entrepreneurial intention.

\subsection{Perceived Behavioral Control does not have a significant effect as a mediator of self-efficacy on entrepreneurial inten- tion.}

Based on the results of statistical calculations carried out in this study, it can be concluded that $(\mathrm{H} 8)$ is rejected, and it is stated that there is no significant influence between the Perceived Behavioral Control variable when it becomes mediated. selfEfficacy towards Entrepreneurial Intention is evidenced by the $t$ value $<1.65$, which is 0.119. So it can be seen in this study that Perceived Behavioral Control does not have a significant effect as a mediator of self-efficacy on entrepreneurial intention.

\subsection{Subjective norms have a significant effect as a self-efficacy mediator on Entrepreneurial Intention.}

Based on the results of statistical calculations carried out by this study, it can be concluded that $(\mathrm{H} 9)$ is accepted and stated that there is a significant influence between 
the subjective norm variable when mediating self-efficacy on entrepreneurial intention, as evidenced by the $t$ value $>1.65$, namely 3.653 . So it can be seen in this study that subjective norms have a significant effect as a mediator of self - efficacy on entrepreneurial intention.

\section{Conclusion}

Based on the results of the discussions that have been carried out and the data analysis from the research results, conclusions can be drawn on the following:

1. Self-efficacy has an effect on attitude toward behavior in MIM at Ciputra University, Surabaya. Based on the PLS test results, it shows that self-efficacy has a significant and positive effect on attitude toward behavior. The higher the level of selfefficacy, the higher the level of attitude toward behavior of MIM students at Ciputra University, Surabaya

2. Self-efficacy has an effect on Perceived Behavioral Control in MIM at Ciputra University, Surabaya. Based on the PLS test results, it shows that self-efficacy has a significant and positive effect on Perceived Behavioral Control. The higher the level of self-efficacy, the higher the level of Perceived Behavioral Control of MIM students at Ciputra University, Surabaya

3. Self-efficacy has an effect on subjective norm control in MIM at Ciputra University Surabaya. Based on the PLS test results, it shows that self-efficacy has a significant and positive effect on subjective norms. The higher the level of self-efficacy, the higher the level of subjective norm of MIM students at Ciputra University, Surabaya.

4. Attitude toward behavior has an effect on Entrepreneurial intention in MIM at Ciputra University, Surabaya. Based on the PLS test results, it shows that attitude toward behavior has a significant and positive effect on Entrepreneurial Intention. The higher the level of attitude toward behavior, the higher the level of Entrepreneurial Intention of MIM students at Ciputra University, Surabaya.

5. Perceived Behavioral Control does not affect Entrepreneurial Intention in MIM at Ciputra University, Surabaya. Based on the PLS test results, it shows that Perceived Behavioral Control does not affect and negatively affects Entrepreneurial Intention. The higher the level of Perceived Behavioral Control, the smaller the level of Entrepreneurial Intention of MIM students at Ciputra University, Surabaya. 
6. Subjective norm has an effect on Entrepreneurial Intention in MIM at Ciputra University, Surabaya. Based on the results of the PLS test, it shows that subjective norm has a significant and positive effect on Entrepreneurial Intention. The higher the subjective norm, the higher the level of Entrepreneurial Intention of MIM students at Ciputra University, Surabaya.

7. Self-efficacy has a significant effect on Entrepreneurial Intention even though it is through attitude toward behavior mediation in MIM at Ciputra University, Surabaya. The PLS test results show that the higher the level of self-efficacy and attitude toward behavior, the higher the level of entrepreneurial intention of MIM students at Ciputra University, Surabaya

8. Perceived Behavioral Control is not an influence or insignificant in the relationship between self-efficacy and entrepreneurial intention. The PLS test results show that the level of Perceived Behavioral Control does not have a positive effect but has a negative effect on the relationship between entrepreneurial intention and entrepreneurial intention. The higher the value of Perceived Behavioral Control, the smaller the value of Entrepreneurial Intention.

9. Self-efficacy has a significant effect on Entrepreneurial Intention even though it is through subjective norm mediation in MIM at Ciputra University Surabaya. The PLS test results show that the higher the level of self-efficacy and subjective norms, the higher the level of entrepreneurial intention of MIM students at Ciputra University, Surabaya.

\section{Funding}

This work is a self-funding research.

\section{Acknowledgement}

The authors would like to thank to the department head and all faculties of the master program of Ciputra Business School. They are also thankful to all the reviewers who gave their valuable inputs to the manuscript and helped in completing the paper.

\section{Conflict of Interest}

The authors have no conflict of interest to declare. 


\section{References}

[1] Hidayat, A. A. N. (2019, October). Retrieved February 14, 2020 from https://bisnis.tempo.co/read/1254508/jumlah-pengusaha-di-indonesia-baru-2persen-dari-total-penduduk.

[2] Astri, W. and Latifah, L. (2017). Pengaruh Personal Attributes, Adversity Quotient dengan Mediasi Self Efficacy Terhadap Minat berwirausaha. Economic Education Analysis Journal, vol. 6, issue 3, pp. 737-751.

[3] Saryanto, S. and Amboningtyas, D. (2017). Pengaruh Rotasi Kerja, Stres, Kepuasan Kerja dan Komitmen Organisasi Terhadap Kinerja Karyawan (Studi Pada Ace Hardware Semarang). Journal of Management, vol. 3, issue 3, pp. 1-10.

[4] Priyanto, D. (2014). SPSS 22 Pengolah Data Terpraktis. Yogyakarta: Andi. 